Research/Technical Note

\title{
Ammonium Di-Hydrogenocitrate and Mono-Hydrogenocitrate Synthesis by Citric Acid Neutralization with Ammonia Using Ethanol as Co-Solvent for the Crystallization - Swelling Test to Confirm Gases Emissions Capacity
}

\author{
Andry Tahina Rabeharitsara, Maheriniaina Andriamasinoro Andriamandroso, \\ Nambinina Richard Randriana, Rijalalaina Rakotosaona, Edouard Andrianarison, \\ André Razafimandefitra, Baholy Robijaona
}

Chemical Process Engineering Department (E. S. P. A), Antananarivo University, Antananarivo, Madagascar

\section{Email address:}

rabeharitsara_andrytahina@yahoo.fr (A. T. Rabeharitsara),maheryandriam@gmail.com (M. A. Andriamasinoro), kotolala@gmail.com (R. Rakotoson), richardrandriana@yahoo.fr (N. R. Randriana), edoravali@yahoo.fr (E. Andrianarison), mandefitra@yahoo.fr (A. Razafimandefitra),holyrobi@yahoo.fr (B. Robijaona)

\section{To cite this article:}

Andry Tahina Rabeharitsara, Maheriniaina Andriamasinoro Andriamandroso, Nambinina Richard Randriana, Rijalalaina Rakotoson, Edouard Andrianarison, André Razafimandefitra, Baholy Robijaona. Ammonium Di-Hydrogenocitrate and Mono-Hydrogenocitrate Synthesis by Citric Acid Neutralization with Ammonia Using Ethanol as Co-Solvent for the Crystallization - Swelling Test to Confirm Gases Emissions Capacity. American Journal of Applied Chemistry. Vol. 6, No. 1, 2018, pp. 6-14. doi: 10.11648/j.ajac.20180601.12

Received: September 11, 2017; Accepted: September 25, 2017; Published: December 23, 2017

\begin{abstract}
Citric acid is a $\alpha$-hydroxylated tricarboxylic acid present in abundance in lemon. More than one million tons of citric acid are industrially produced throughout the year. Our objective in this manuscript was to increase the value of the citric acid to ammonium citric acid salts by crystallization such as ammonium Di-hydrogenocitrate and ammonium mono-hydrogenocitrate. Studies and tests were carried out in this direction but the characteristic of our last process was the use of a co-solvent ethanol which proved more effective and more economical. At the end, we tested the capacity of the ammonium Di-hydrogenocitrate and the ammonium mono-hydrogenocitrate to swell a mixture and compared theirs capacities to the sodium bicarbonate. Results showed an excellent swelling capacity of the ammonium Di-hydrogenocitrate and ammonium mono-hydrogenocitrate to produce a uniformly very not much porous product's texture.
\end{abstract}

Keywords: Citric Acid, Ammonia, Ethanol, Crystallization, Co-solvent Crystallization, Ammonium Di-hydrogenocitrate, Ammonium Mono-hydrogenocitrate, Sodium Bicarbonate, Swelling Test

\section{Introduction}

Citric acid which is a tricarboxylic acid was neutralized by ammonia. According to the solution's pH, we obtained either ammonium Di-hydrogenocitrate either mono-hydrogenocitrate which are citric acid salts and have their future in agricultural, food and medicinal fields like calcium citrate and sodium citrate [1]. Studies on the effectiveness of the use of ethanol as co-solvent during the crystallization were made [2] and we have used this method.
Immediately, ammonium salts were formed. They were treated then we tested their capacity to swell a mixture by following a cooking procedure. Uniformly very not much porous texture was obtained which confirmed not only ammonia and carbon dioxide gases emissions but also water and molecules formations by esterification between citric acids and starches molecules. 


\section{Citric Acid}

\subsection{Citric Acid Generalities}<smiles>[R16][Y19]=[W]</smiles>

Figure 1. 3-hydroxypropane-1, 2, 3-tricarboxylic acid (Citric Acid).

Citric acid $\mathrm{C}_{6} \mathrm{H}_{8} 0_{7}$ is a tricarboxylic acid $\alpha$ - hydrolyzed. It contains three acids with pKa such as $\mathrm{pKa}_{1}=3.14, \mathrm{pKa}_{2}=$ 4.77 and $\mathrm{pKa}_{3}=6.39$ and an $\alpha$-alcohol function with $\mathrm{pKa}=$
$14.4[3,4,5,6]$ "Figure 1". By its reactivity, the citric acid was the object of several studies and was used in several fields like the cosmetics, the food one, the chemistry and others [7].

We noticed that the acid form is $\mathrm{AH}$ with $\mathrm{pKa}(\mathrm{AH})$. It was shown that if the $\mathrm{pH} \leq[\mathrm{pKa}(\mathrm{AH})-2]$, the quantity of basic $\mathrm{A}^{-}$ associated to the acid/base couple $\mathrm{AH} / \mathrm{A}^{-}$is negligible in comparison with the $\mathrm{AH}$ quantity. And if the $\mathrm{pH} \geq[\mathrm{pKa}(\mathrm{AH})$ $+2]$, the quantity of acid $\mathrm{AH}$ associated to the acid/base couple $\mathrm{AH} / \mathrm{A}^{-}$is negligible in comparison with the $\mathrm{A}^{-}$quantity [8]. For $[\mathrm{pKa}(\mathrm{AH})-2] \leq \mathrm{pH} \leq[\mathrm{pKa}(\mathrm{AH})+2]$, the basic $\mathrm{A}^{-}$ and the acid $\mathrm{AH}$ forms coexist but if $[\mathrm{pKa}(\mathrm{AH})-2] \leq \mathrm{pH} \leq$ $\mathrm{pKa}(\mathrm{AH})$ the acid form $\mathrm{AH}$ dominate and if $\mathrm{pKa}(\mathrm{AH}) \leq \mathrm{pH} \leq$ $[\mathrm{pKa}(\mathrm{AH})+2]$ the basic form $\mathrm{A}^{-}$dominate [8]. Consequently, for the citric acid we noted in the following Table 1 the acids and basics forms according to the $\mathrm{pKa}$ and $\mathrm{pH}$ :

Table 1. Dominant Forms of "Citric Acid" According to the pH.

\begin{tabular}{|c|c|c|c|c|c|}
\hline pH & Acid/base couple & pKa & Acid/Base reactions & Dominant forms & Dominant molecule/Ions \\
\hline $\mathrm{pH} \leq 3.14$ & $\mathrm{AH}_{3} / \mathrm{AH}_{2}^{-}$ & 3.14 & $\mathrm{AH}_{3} \longleftrightarrow \mathrm{AH}_{2}^{-}+\mathrm{H}^{+}$ & $\mathrm{AH}_{3}$ & Citric Acid \\
\hline $3.14 \leq \mathrm{pH} \leq 4.77$ & $\mathrm{AH}_{2}^{-} / \mathrm{AH}^{2-}$ & 4.77 & $\mathrm{AH}_{2}^{-} \longrightarrow \mathrm{AH}^{2-}+\mathrm{H}^{+}$ & $\mathrm{AH}_{2}^{-}$ & Di-Hydrogenocitrate \\
\hline $4.77 \leq \mathrm{pH} \leq 6.39$ & $\mathrm{AH}^{2-1} \mathrm{~A}^{3-}$ & 6.39 & $\mathrm{AH}^{2-} \quad \longrightarrow \quad \mathrm{A}^{3-}+\mathrm{H}^{+}$ & $\mathrm{AH}^{2-}$ & Mono-Hydrogenocitrate \\
\hline
\end{tabular}

\subsection{Characteristics of Citric Acid}

Citric acid is solid with monoclinic as crystal structure, white, odorless and excessively sour flavor (Table 2) [4]. Citric acid exists in hydrates forms, the monohydrate melts towards $343.15^{\circ} \mathrm{K}$ and the anhydrous state melting point is $426.15^{\circ} \mathrm{K}$. Citric acid is soluble in alcohol, ether, ethyl acetate and DMSO and insoluble in $\mathrm{C}_{6} \mathrm{H}_{6}, \mathrm{CHCl}_{3}, \mathrm{CS}_{2}$, and toluene. Its solubility in ethanol at $298.15^{\circ} \mathrm{K}$ is $62 \mathrm{~g} / 100 \mathrm{~g}$. Citric acid is very soluble in water and its solubility increases with the temperature as shown the following table (Table 3) [9].
Table 2. Citric Acid Physicochemical Properties.

\begin{tabular}{ll}
\hline Physicochemical Properties & CITRIC ACID - $\mathbf{C}_{6} \mathbf{H}_{8} \mathbf{0}_{7}$ \\
\hline Appearance & Crystalline white solid \\
Crystal structure & Monoclinic \\
Molar mass & $192.12\left[\mathrm{~g} \cdot \mathrm{mol}^{-1}\right]$ \\
Density & $1.665\left[\mathrm{~g} \cdot \mathrm{cm}^{-3}\right]$ anhydrous \\
& $1.542\left[\mathrm{~g} \cdot \mathrm{cm}^{-3}\right]$ monohydrate at $291.15^{\circ} \mathrm{K}$ \\
Melting point & $426.15^{\circ} \mathrm{K}$ anhydrous \\
Boiling point & $343.15^{\circ} \mathrm{K}$ monohydrate \\
Solubility in ethanol & $448.15^{\circ} \mathrm{K}$ \\
Solubility in water & $62 \mathrm{~g} / 100 \mathrm{~g}$ \\
\hline
\end{tabular}

Table 3. Evolution of the Citric Acid Solubility in Water (w/w) Following to the Temperature ( $\left.{ }^{\circ} \mathrm{K}\right)$.

\begin{tabular}{llllllllll}
\hline $\mathrm{T}^{\circ} \mathrm{K}$ & 283.15 & 293.15 & 303.15 & 313.15 & 323.15 & 333.15 & 343.15 & 353.15 & 363.15 \\
Solubility $(\% \mathrm{~g} / 100 \mathrm{mg})$ & 54.0 & 59.2 & 64.3 & 68.6 & 70.9 & 73.5 & 76.2 & 78.8 & 81.4 \\
\hline
\end{tabular}

\section{Ammonia (Ammonium Hydroxide)}

\subsection{Ammonium Hydroxide Generalities}

Ammonium hydroxide is a colorless aqueous solution obtained by the solubilization of ammonia in water $[4,11,12]$ according to the reaction

$$
\mathrm{NH}_{3}+\mathrm{H}_{2} \mathrm{O} \leftrightarrow \mathrm{NH}_{4}^{+}+\mathrm{OH}^{-}
$$

with $\mathrm{pKa}$ (Dissociation constant of the couple Acid/Base $\left.\mathrm{NH}_{4}^{+} / \mathrm{NH}_{3}\right)=9.2$ [11].

We noticed again that the acid form is $\mathrm{AH}$ with $\mathrm{pKa}(\mathrm{AH})$. It was shown that if the $\mathrm{pH} \leq[\mathrm{pKa}(\mathrm{AH})-2]$, the quantity of basic $\mathrm{A}^{-}$associated to the acid/base couple $\mathrm{AH} / \mathrm{A}^{-}$is negligible in comparison with the $\mathrm{AH}$ quantity. And if the $\mathrm{pH} \geq[\mathrm{pKa}(\mathrm{AH})$ $+2]$, the quantity of acid $\mathrm{AH}$ associated to the acid/base couple $\mathrm{AH} / \mathrm{A}^{-}$is negligible in comparison with the $\mathrm{A}^{-}$quantity [8]. For $[\mathrm{pKa}(\mathrm{AH})-2] \leq \mathrm{pH} \leq[\mathrm{pKa}(\mathrm{AH})+2]$, the basic $\mathrm{A}^{-}$ and the acid $\mathrm{AH}$ forms coexist but if $[\mathrm{pKa}(\mathrm{AH})-2] \leq \mathrm{pH} \leq$ $\mathrm{pKa}(\mathrm{AH})$ the acid form $\mathrm{AH}$ dominate and if $\mathrm{pKa}(\mathrm{AH}) \leq \mathrm{pH} \leq$ $[\mathrm{pKa}(\mathrm{AH})+2]$ the basic form $\mathrm{A}^{-}$dominate [8]. Consequently, for the ammonia we noted in the following table 4 the acids and basics forms according to the $\mathrm{pKa}$ and $\mathrm{pH}$ :

Table 4. Dominant Forms of Ammonia in Couple Acid/Base $\mathrm{NH}_{4}{ }^{+} / \mathrm{NH}_{3}$ According to the $\mathrm{pH}$.

\begin{tabular}{|c|c|c|c|c|c|}
\hline pH & Acid/base couple & pKa & Acid/Base reactions & Dominant forms & Dominant molecule/Ions \\
\hline $\mathrm{pH} \leq 9.2$ & $\mathrm{NH}_{4}^{+} / \mathrm{NH}_{3}$ & 9.2 & $\mathrm{NH}_{4}^{+}+\mathrm{OH}^{-} \rightleftarrows \mathrm{NH}_{3}+\mathrm{H}_{2} 0$ & $\mathrm{NH}_{4}^{+}$ & Ammonia Ion \\
\hline $9.2 \leq \mathrm{pH}$ & $\mathrm{NH}_{4}^{+} / \mathrm{NH}_{3}$ & 9.2 & $\mathrm{NH}_{4}{ }^{+}+\mathrm{OH}^{-} \longrightarrow \mathrm{NH}_{3}+\mathrm{H}_{2} \mathrm{O}$ & $\mathrm{NH}_{3}$ & Ammoniac $\left(\mathrm{NH}_{3}\right)$ \\
\hline
\end{tabular}




\subsection{Characteristics of Ammonia (Ammonium Hydroxide)}

The concentration of ammonia ranges up to approximately $30 \%$. Its solution irritates eyes and suffocating odor confirms the presence of ammonium hydroxide which is relatively very volatile. The boiling point of ammonia $25 \%$ is $311.15^{\circ} \mathrm{K}[10]$.

Table 5. Ammonium Hydroxide Physicochemical Properties.

\begin{tabular}{ll}
\hline Physicochemical Properties & AMMONIUM HYDROXIDE $-\mathrm{NH}_{4} \mathrm{OH}$ \\
\hline Appearance & Colorless liquid \\
Odor & Intense, pungent, suffocating odor \\
Molar mass & $35.037\left[\mathrm{~g} \cdot \mathrm{mol}^{-1}\right]$ \\
Density & $0.90\left[\mathrm{~g} \cdot \mathrm{cm}^{-3}\right]$ at $298.15^{\circ} \mathrm{K}$ \\
Melting point & $215.15^{\circ} \mathrm{K}$ at $25 \%$ \\
Boiling point & $311.15^{\circ} \mathrm{K}$ at $25 \%$ \\
Solubility in ethanol $(95 \%)$ & Miscible \\
Solubility in water & Miscible \\
\hline
\end{tabular}<smiles></smiles>

Figure 2. Ammonium Citrate.

\section{Ammonium Citrate, Ammonium Di-hydrogenocitrate, Ammonium Mono-hydrogenocitrate}

\subsection{Ammonium Citrate (Formula and Characteristics)}

The Ammonium citrate or Triammonium citrate (Figure 2) was salt obtained by acid/base reaction between citric acid $\left(\mathrm{C}_{6} \mathrm{H}_{8} \mathrm{O}_{7}\right)$ as acid and ammonia (Ammonium Hydroxide $\left.\mathrm{NH}_{4} \mathrm{OH}\right)$ as base. It was shown that the respect of the couple Citric acid (acid)/Ammonia (base) solution's pH (cf. \$2.1 $\S 3.1$ ) (Table 1) and crystallization temperature controls led to the tri-ammonium citrate salt formation $[13,15]$. We putted 150 [g] of citric acid with 234.23 [ml] of ammonium hydroxide $(25 \%)$ in a baker, the solution's $\mathrm{pH}$ is on 9.45 . According to the table 1 and the table 4, the dominant form of ions are $\mathrm{A}^{3-}$ and $\mathrm{NH}_{4}^{+}$. Then, baker was carried in a $373.15^{\circ} \mathrm{K}$ water bath during $60 \mathrm{mn}$ to evaporate the water and to decrease the solubility of the tri-ammonium citrate formed. Then, the solution became tri-ammonium saturated and to increase the amount of this salt we brought this saturated solution to labile region which is over the metastable limit by cooling the baker on magnetic stirrer [14]. After filtration on filter paper, we obtained odorless white crystals of slightly acid tri-ammonium citrate $\left(\mathrm{C}_{6} \mathrm{H}_{17} \mathrm{~N}_{3} \mathrm{O}_{7}\right)$ [13].

\subsection{Ammonium Di-hydrogenocitrate and Ammonium Mono-hydrogenocitrate}

We synthesized the Ammonium Di-hydrogenocitrate $\left(\mathrm{AH}_{2}{ }^{-} / \mathrm{NH}_{4}^{+}\right)$and mono-hydrogenocitrate $\left(\mathrm{AH}^{2-} / 2 \mathrm{NH}_{4}^{+}\right)$. We putted $250[\mathrm{~g}]$ of citric acid with 39 [ml] of ammonium hydroxide $(25 \%)$ in a baker, the solution's $\mathrm{pH}$ is on 3.55 . According to the table 1 and the table 4 , the dominant form of ions is $\mathrm{AH}_{2}{ }^{-}$and $\mathrm{NH}^{4+}$. Then, baker was carried in a $373.15^{\circ} \mathrm{K}$ water bath during $60 \mathrm{mn}$ to evaporate the water and to decrease the solubility of the Ammonium Di-hydrogenocitrate formed. Then, the solution became Ammonium Di-hydrogenocitrate saturated and to increase the amount of this salt we brought this saturated solution to labile region which is over the metastable limit by cooling the baker on magnetic stirrer [14]. After filtration on filter paper, we obtained odorless white crystals of Ammonium Di-hydrogenocitrate [Figure 3] salts which taste acid [13].

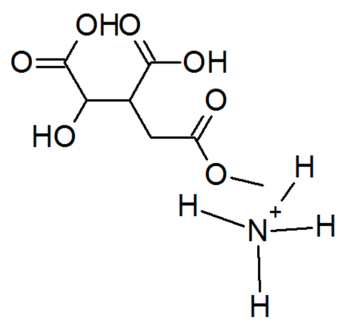

Figure 3. Ammonium Di-hydrogenocitrate.

To obtain the mono-hydrogenocitrate [Figure 4] we brought the $\mathrm{pH}$ of solution between 4.77 and 6.39 by putting 9.6 [g] of citric acid with $20[\mathrm{ml}]$ of ammonium hydroxide $(25 \%)$ in a baker. According to the table 1 and the table 4, the dominant form of ions are $\mathrm{AH}^{2-}$ and $\mathrm{NH}_{4}^{+}$. Then, baker was carried in a $373.15^{\circ} \mathrm{K}$ water bath during $60 \mathrm{mn}$ to evaporate the water and to decrease the solubility of the mono-hydrogenocitrate formed. Then, the solution became mono-hydrogenocitrate saturated and to increase the amount of this salt we brought this saturated solution to labile region which is over the metastable limit by cooling the baker on magnetic stirrer [14]. After filtration on filter paper, we obtained odorless white crystals of mono-hydrogenocitrate $\left(\mathrm{AH}^{2-} / 2 \mathrm{NH}_{4}{ }^{+}\right)$salts which taste non-acid [13].

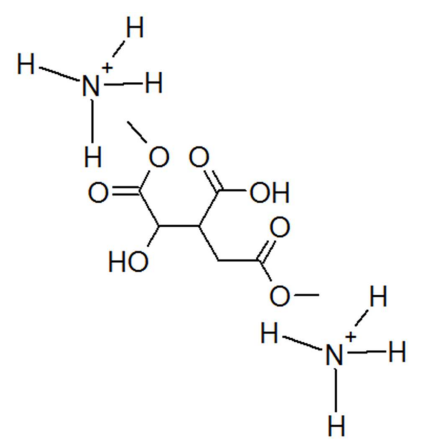

Figure 4. Ammonium Mono-hydrogenocitrate.

To summarize we put in the following figure (Figure 5) the 
Ammonium citrate, Ammonium Di-hydrogenocitrate and Ammonium mono-hydrogenocitrate crystallization procedure [13]. The output of ammonium salts was all the time over $100 \%$ because of water presence (Hydrated salts - Figure 2). To limit the water presence and to improve the quality of the ammonium salts we elaborated a new procedure using a co-solvent [14] miscible with water, ammonium hydroxide, soluble in citric acid but practically insoluble in Ammonium Di-hydrogenocitrate and Ammonium mono-hydrogenocitrate: ethanol which is not only healthy but also an environmentally responsible solvent than methanol.

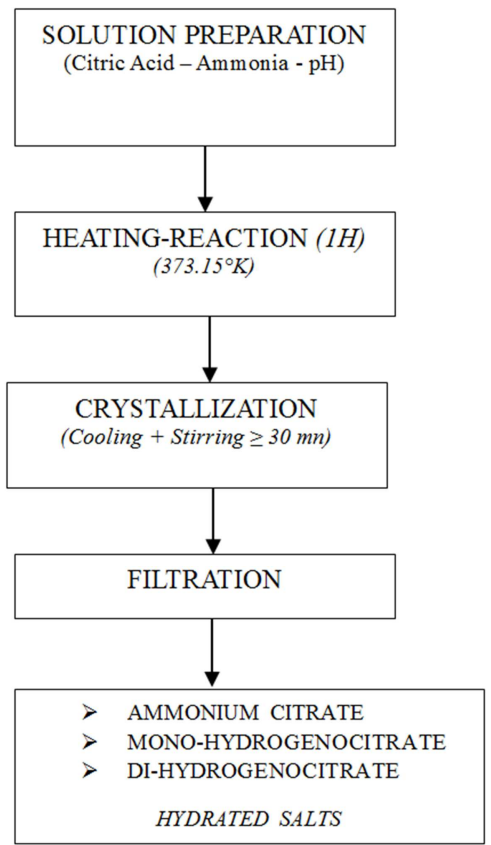

Figure 5. Ammonium Citrates Salts Crystallization Procedure.

\section{Procedure Used for Ammonium Di-hydrogenocitrate and Mono-hydrogenocitrate Synthesis: Salts Precipitation Using the Co-solvent Ethanol}

\subsection{Equipment and Chemicals}

To synthesize the Ammonium Di-hydrogenocitrate $\left(\mathrm{AH}_{2}^{-} /\right.$ $\left.\mathrm{NH}_{4}^{+}\right)$and the ammonium mono-hydrogenocitrate $\left(\mathrm{AH}^{2-} / 2\right.$ $\mathrm{NH}_{4}^{+}$) by precipitation using a co-solvent ethanol we used:

- Citric acid (C6H807)

- Ammonium Hydroxide 25\% (NH4OH)

- Ethanol 97\% (C2H5OH)

- Baker

- Spatula

- Precision scales

- Thermometer

- Magnetic Stirrer

- PH-meter

- Filter paper
- Funnel

- A drying oven

- Test tube

\subsection{Procedure}

We putted $62[\mathrm{~g}]$ of citric acid with 9.8 [ml] of ammonium hydroxide $(25 \%)$ in a baker, the solution's $\mathrm{pH}$ is on 3.5 . According to the table 1 and the table 4, the dominant form of ions are $\mathrm{AH}_{2}^{-}$and $\mathrm{NH}_{4}^{+}$. Then, baker was carried in a $313.15^{\circ} \mathrm{K}$ water bath during $15 \mathrm{mn}$. Critical nucleus of the new solid phase "Ammonium Di-hydrogenocitrate salt" is formed. We are on region between undersatureted regions and metastable limits. To accelerate the formation of the solid phase and to reduce its solubility in water, we cooled the baker and we used the co-solvent ethanol $97 \%$ which is not only miscible in water but also naturally cool $[14,15,16]$. It was shown that $\mathrm{c}^{*}$, the equilibrium saturation concentration value, is empirically correlated with the concentration of the co-solvent $x$ like $\ln \left[\mathrm{C}^{*}\right]=\mathrm{A}+\mathrm{Bx}+\mathrm{Cx} 2$. In this case, we used a quantity of ethanol which didn't bring the $\mathrm{pH}$ of solution more than 4.77 and stirred the solution baker. Instantaneously, the Ammonium Di-hydrogenocitrate precipitation occurs, we are on the labile region [14]. After a few minutes, we filtered the Ammonium Di-hydrogenocitrate with a filter paper and dried it in a drying oven. Knowing that the ethanol boiling point is 351.39 [ $\left.{ }^{\circ} \mathrm{K}\right]$ [17] and it's completely miscible in water with the possibility of having hydrogen bond connections with oxygens and hydrogens molecules of water and ammonium citric acid salts [18], drying with temperature higher than $358.15\left[{ }^{\circ} \mathrm{K}\right.$ ] is used to eliminate not only the rest of water molecules but also ethanol molecules. Then, we obtained odorless white crystals of Ammonium Di-hydrogenocitrate salts which taste acid.

To obtain the mono-hydrogenocitrate we brought the $\mathrm{pH}$ of solution at 5.5 (between 4.77 and 6.39 - cf. Table 1 ) by putting 62 [g] of citric acid with 15.8 [ml] of ammonium hydroxide $(25 \%)$ in a baker. According to the table 1 and the table 4, the dominant form of ions are $\mathrm{AH}^{2-}$ and $\mathrm{NH}_{4}^{+}$. Then, baker was carried in a $313.15{ }^{\circ} \mathrm{K}$ water bath during $15 \mathrm{mn}$. Critical nucleus of the new solid phase "Ammonium mono-hydrogenocitrate salt" is formed. We are on region between undersatureted regions and metastable limits. To accelerate the formation of the solid phase and to reduce its solubility in water, we cooled the baker and we used the co-solvent ethanol $97 \%$ which is not only miscible in water but also naturally cool $[14,15,16]$. In this case, we used a quantity of ethanol which didn't bring the $\mathrm{pH}$ of solution more than 6.5 and stirred the solution baker. Instantaneously, the Ammonium Di-hydrogenocitrate precipitation occurs, we are on the labile region [14]. After a few minutes, we filtered the Ammonium mono-hydrogenocitrate with a filter paper and dried it in a drying oven. Knowing that the ethanol boiling point is 351.39 [ ${ }^{\circ} \mathrm{K}$ ] [17] and it's completely miscible in water with the possibility of having hydrogen bond connections with oxygens and hydrogens molecules of water and ammonium citric acid salts [18], drying with temperature higher than $358.15\left[{ }^{\circ} \mathrm{K}\right]$ is used to eliminate not only the rest of water 
molecules but also ethanol molecules. Then we obtained odorless white crystals of Ammonium mono-hydrogenocitrate salts which taste non-acid.

To summarize we put in the following figure (Figure 6) the Ammonium Di-hydrogenocitrate and Ammonium mono-hydrogenocitrate precipitation procedure using a co-solvent ethanol.

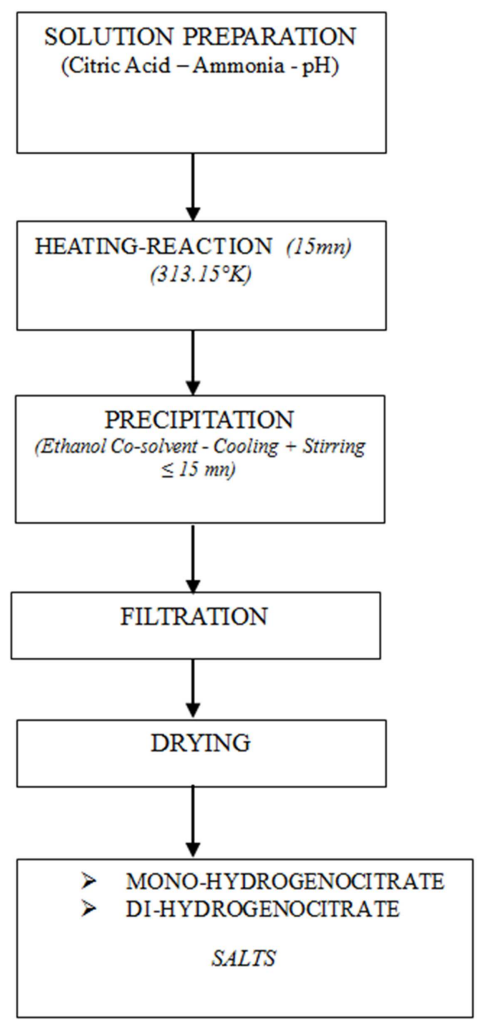

Figure 6. Ammonium Di-hydrogenocitrate and Ammonium MONO-hydrogenocitrate Precipitation Procedure Using a Co-solvent Ethanol.

\section{Results}

\subsection{Ammonium Di-hydrogenocitrate and Ammonium Mono-hydrogenocitrate Yields Using Co-solvent Ethanol Precipitation Procedure}

Compared with the crystallization procedure (figure 2), the precipitation procedure using a co-solvent ethanol was not only rapid but also energetically profitable. In the following table, we show the yields of Ammonium Di-hydrogenocitrate and ammonium mono-hydrogenocitrate obtained by the precipitation procedure.

\subsection{Ethanol Solubility of the Ammonium \\ Di-hydrogenocitrate and the Ammonium \\ Mono-hydrogenocitrate Obtained by Co-solvent Ethanol Precipitation Procedure}

Bibliography informs us that the ammonium mono-hydrogenocitrate is very slightly soluble in ethanol [19]. To confirm this solubility to our ammonium mono-hydrogenocitrate (Table 6), we used the oversaturated method. In this case, solid in excess of the amount required for saturation is added to the solvent and agitated until apparent equilibrium is reached [14]. At ambient temperature, we took $2[\mathrm{~g}]$ of ammonium mono-hydrogenocitrate into 2 [ml] of ethanol (97\%) using a test tube. After prolonged agitated contact, the weight of the rest of ammonium mono-hydrogenocitrate was 1.950 [g]. That is to say, only 0.05 [g] of ammonium mono-hydrogenocitrate was soluble in ethanol (97\%) and considering that the solubility of the ammonium mono-hydrogenocitrate in water is $1 \mathrm{mg} / 1 \mathrm{mg}$ [19], this solubility is exactly 0.0485 [g] in ethanol $(100 \%)$; it correspond to $2.425 \%$ of the initial weight and confirm that the ammonium mono-hydrogenocitrate is very slightly soluble in ethanol.

We used the same method to determine the solubility of the ammonium Di-hydrogenocitrate in ethanol. At ambient temperature, we took 2 [g] of ammonium Di-hydrogenocitrate into $2[\mathrm{ml}]$ of ethanol (97\%) using a test tube. After prolonged agitated contact, the weight of the rest of ammonium mono-hydrogenocitrate was 1.935 [g]. That is to say, only 0.065 [g] of ammonium mono-hydrogenocitrate was soluble in ethanol $(97 \%)$; it correspond to $3.25 \%$ of the initial weight and confirm that also the ammonium Di-hydrogenocitrate is very slightly soluble in ethanol. But, after comparison we saw that, the ammonium Di-hydrogenocitrate was more soluble in ethanol (97\%) than the ammonium mono-hydrogenocitrate at ambient temperature.

Table 6. Ammonium Di-hydrogenocitrate and Ammonium Mono-hydrogenocitrate Yields Using Co-solvent Ethanol Precipitation Procedure.

\begin{tabular}{|c|c|c|}
\hline & Ammonium Di-hydrogenocitrate $\left(\mathrm{AH}_{2}{ }^{-} / \mathrm{NH}_{4}{ }^{+}\right)$ & Ammonium mono-hydrogenocitrate $\left(\mathrm{AH}^{2-} / 2 \mathrm{NH}_{4}{ }^{+}\right)$ \\
\hline Citric acid $\left(\mathrm{C}_{6} \mathrm{H}_{8} \mathrm{O}_{7}\right)[\mathrm{g}]$ & $62[\mathrm{~g}]$ & $62[\mathrm{~g}]$ \\
\hline Ammonium Hydroxide $25 \%\left(\mathrm{NH}_{4} \mathrm{OH}\right)[\mathrm{ml}]$ & $9.8[\mathrm{ml}]$ & $15.8[\mathrm{ml}]$ \\
\hline + Ethanol $97 \%\left(\mathrm{C}_{2} \mathrm{H}_{5} \mathrm{OH}\right)(\mathrm{Co}$-solvent $)$ & $25[\mathrm{ml}](\mathrm{pH}<4.77)$ & $25[\mathrm{ml}](\mathrm{pH}<6.5)$ \\
\hline Solution $\mathrm{pH}$ & $\mathrm{pH} \approx 3.5(<4.77)$ & $\mathrm{pH} \approx 5.5(<6.5)$ \\
\hline \multirow[t]{2}{*}{ Yields (\%) } & $77.42[\%]$ & $82.26[\%]$ \\
\hline & Ammonium Di-hydrogenocitrate $\left(\mathrm{AH}_{2}^{-} / \mathrm{NH}_{4}^{+}\right)$ & Ammonium mono-hydrogenocitrate $\left(\mathrm{AH}^{2-} / 2 \mathrm{NH}_{4}^{+}\right)$ \\
\hline Citric acid $\left(\mathrm{C}_{6} \mathrm{H}_{8} \mathrm{O}_{7}\right)[\mathrm{g}]$ & $62[\mathrm{~g}]$ & $62[\mathrm{~g}]$ \\
\hline+ Ethanol $97 \%\left(\mathrm{C}_{2} \mathrm{H}_{5} \mathrm{OH}\right)(\mathrm{Co}$-solvent $)$ & $25[\mathrm{ml}](\mathrm{pH}<4.77)$ & $25[\mathrm{ml}](\mathrm{pH}<6.5)$ \\
\hline Solution $\mathrm{pH}$ & $\mathrm{pH} \approx 3.5(<4.77)$ & $\mathrm{pH} \approx 5.5(<6.5)$ \\
\hline Yields $(\%)$ & $77.42[\%]$ & $82.26[\%]$ \\
\hline
\end{tabular}




\section{Swelling Tests of the Ammonium Di-hydrogenocitrate and Mono-hydrogenocitrate Salts}

The objective of this part was to test the capacity of the Ammonium Di-hydrogenocitrate and the Ammonium mono-hydrogenocitrate to swell a mixture. As we see, these salts contains ammonium function (from $-\mathrm{ONH}_{4}$ ) (Figure 3 - Figure 4) which can generate the ammonia $\left(\mathrm{NH}_{3}\right)$ (Table 4 - Table 5) and acids functions (from the citric acid function) which catalyzed the ammonia reactions formation (Figure 7 - Figure 8) [20]. In addition, we noticed that according to the Van't Hoff equation the $\mathrm{pKa}$ value was influenced by the temperature [21]. In the end, we compared these salts and the sodium bicarbonate baking powder (rising powder) capacity to swell a mixture.

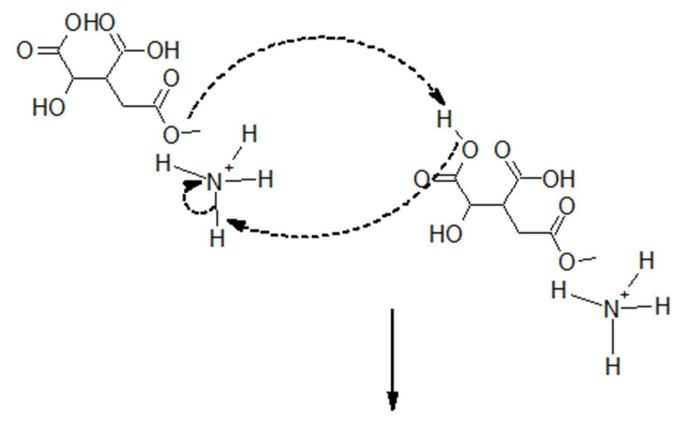

$$
=\mathrm{OH}_{\mathrm{OH}}^{\mathrm{OHOH}}
$$

Figure 7. Ammonia and Citric Acid Formed by Ammonium Di-hydrogenocitrate Transformation.

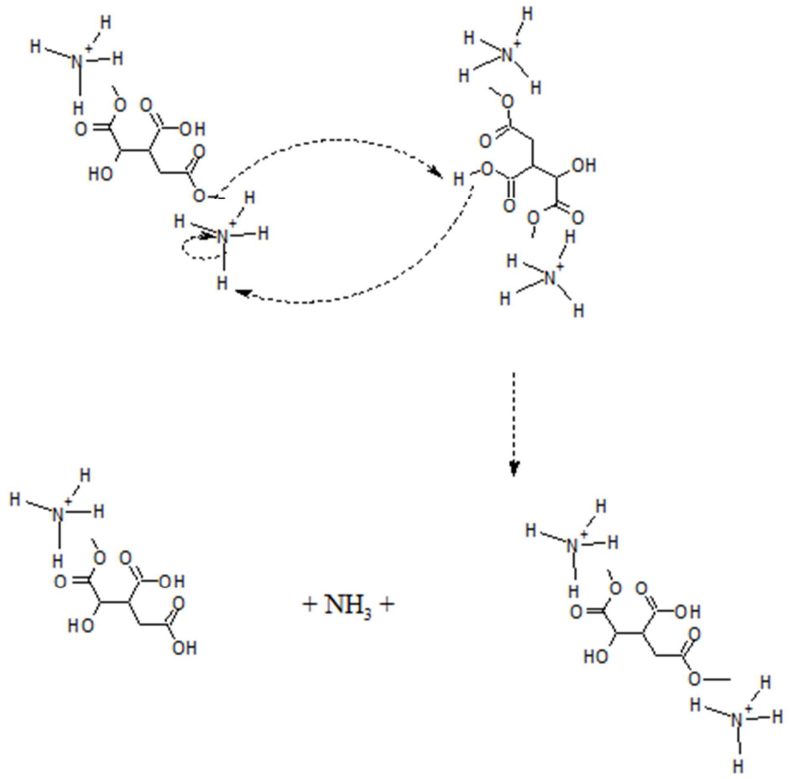

Figure 8. Ammonia and Ammonium Mono-hydrogenocitrate Formed by Ammonium Mono-hydrogenocitrate Transformation.

With water, we noticed that the ammonia can formed $\mathrm{NH}_{4} \mathrm{OH}$ according to the $\mathrm{pH}$ and the temperature (Table $4-$ Table 5) [21].

\subsection{Sodium Bicarbonate and Ammonium Bicarbonate Baking Powder Swelling Characteristics}

Baking powders are white powders used to swell biscuits and pastry during cooking. According to their natures, they produced carbon dioxide (Sodium bicarbonate - Figure 9) and or ammonia (Ammonium bicarbonate - Figure 10) with water. The paste swelled and developed. Then, cavities and pores was been left by these gases and steams emission (Table 7) - [22].

Table 7. Dominant Forms of $\mathrm{CO}_{2}$ in Couple Acid/Base $\mathrm{H}_{2} \mathrm{O}, \mathrm{CO}_{2} / \mathrm{HCO}_{3}{ }^{-}$According to the pH. [11].

\begin{tabular}{lllll}
\hline $\mathbf{p H}$ & Acid/base couple & pKa & Acid/Base reactions & Dominant forms \\
\hline $\mathrm{pH} \leq 6.4$ & $\mathrm{H}_{2} \mathrm{O}, \mathrm{CO}_{2} / \mathrm{HCO}_{3}^{-}$ & 6.4 & $\mathrm{H}_{2} \mathrm{O}+\mathrm{CO}_{2}+\mathrm{H}_{2} \mathrm{O} \longrightarrow$ & $\mathrm{HCO}_{3}^{-}+\mathrm{H}^{+}+\mathrm{H}_{2} \mathrm{O}$ \\
$6.4 \leq \mathrm{pH}$ & $\mathrm{H}_{2} \mathrm{O}, \mathrm{CO}_{2} / \mathrm{HCO}_{3}^{-}$ & 6.4 & $\mathrm{H}_{2} \mathrm{O}+\mathrm{CO}_{2}+\mathrm{H}_{2} \mathrm{O} \longrightarrow \longrightarrow \mathrm{HCO}_{3}^{-}+\mathrm{H}^{+}+\mathrm{H}_{2} \mathrm{O}$ \\
\hline
\end{tabular}

$$
\mathrm{NaHCO}_{3} \longrightarrow \mathrm{Na}^{+}+\mathrm{HCO}_{3}+\mathrm{H}_{3} \mathrm{O}^{+} \stackrel{\mathrm{pH} \leq 6.4}{\longrightarrow} \mathrm{Na}^{+}+2 \mathrm{H}_{2} \mathrm{O}+\mathrm{CO}_{2}
$$

Figure 9. Decomposition Reaction of the Sodium Bicarbonate.

$$
\mathrm{NH}_{4} \mathrm{HCO}_{3} \longrightarrow \mathrm{NH}_{4}^{+}+\mathrm{HCO}_{3}+\mathrm{H}_{3} \mathrm{O}^{+} \stackrel{\mathrm{T}\left[{ }^{\circ} \mathrm{K}\right], \mathrm{pH} \leqslant 6.4}{\longleftarrow} \mathrm{NH}_{3}+\mathrm{H}_{2} \mathrm{O}+\mathrm{CO}_{2}+\mathrm{H}_{3} \mathrm{O}^{+}
$$

According to the figure 7, figure 8 and figure 9 we showed in the following table 8 the theoretical swelling capacity of the ammonium Di-hydrogenocitrate, the ammonium mono-hydrogenocitrate and the sodium bicarbonate by respectively $\mathrm{NH}_{3}$ and $\mathrm{CO}_{2}$ gas emission with water.

\begin{tabular}{|c|c|c|c|c|c|c|c|c|}
\hline \multirow{2}{*}{ SALTS } & \multicolumn{2}{|c|}{ SALTS Quantity } & \multicolumn{2}{|c|}{$\mathrm{NH}_{3}$ gas emission } & \multicolumn{2}{|c|}{$\mathrm{CO}_{2}$ gas emission } & \multicolumn{2}{|l|}{ Water } \\
\hline & Mass [g] & Moles & Mass [g] & Moles & Mass [g] & Moles & Mass [g] & Moles \\
\hline$\left(\mathrm{AH}_{2}{ }^{-} / \mathrm{NH}_{4}{ }^{+}\right)$ & 1 & $4.782 \times 10^{-3}$ & $8.13 \times 10^{-2}$ & $4.782 \times 10^{-3}$ & - & - & - & - \\
\hline$\left(\mathrm{AH}^{2-} / 2 \mathrm{NH}_{4}^{+}\right)$ & 1 & $4.422 \times 10^{-3}$ & $15.04 \times 10^{-2}$ & $8.845 \times 10^{-3}$ & - & - & - & - \\
\hline $\mathrm{NaHCO}_{3}$ & 1 & $11.905 \times 10^{-3}$ & - & - & $52.8 \times 10^{-2}$ & $11.905 \times 10^{-3}$ & $43.2 \times 10^{-2}$ & $23.81 \times 10^{-3}$ \\
\hline
\end{tabular}

Figure 10. Decomposition Reaction of the Ammonium Bicarbonate.

Table 8. Theoretical Swelling Capacity of Salts. 
We noticed that at the same quantity $1[\mathrm{~g}]$, the $\mathrm{NaHCO}_{3}$ salt should have 2.5 times and 1.4 times capacity to swell than respectively the ammonium Di-hydrogenocitrate and the ammonium mono-hydrogenocitrate salts considering only the $\mathrm{NH}_{3}$ and $\mathrm{CO}_{2}$ gas emission. However, it was shown that

water was not only the solvent which is the responsible of the ingredients repartition but its evaporation was also responsible of the porous formation [22]. Consequently, the ammonium Di-hydrogenocitrate and the ammonium mono-hydrogenocitrate should have respectively less 7.5 times and 4.1 times capacity to swell than the sodium carbonate. Discussions and explanations about the swelling salts capacities will be broached at the paragraph 7.3.

\subsection{Cooking Procedure}

During the swelling capacity tests of ammonium Di-hydrogenocitrate and ammonium mono-hydrogenocitrate in comparison with sodium bicarbonate [23]. We adopted the following cooking procedure: we preheated the oven at $423.15\left[{ }^{\circ} \mathrm{K}\right]$ and prepared the mixture in the cake pan. When the $423.15^{\circ} \mathrm{C}$ was stable we putted the mixture in the oven. We progressively increased the temperature at $473.15^{\circ} \mathrm{C}$. The cooking at $473.15^{\circ} \mathrm{C}$ lasted $30[\mathrm{mn}]$ after which we took out the product obtained.

\subsection{Tests Results and Comparisons, Discussions}

About the swelling tests, we prepared cake pastries using respectively $3[\mathrm{~g}]$ of ammonium Di-hydrogenocitrate, ammonium mono-hydrogenocitrate and sodium carbonate. Then, we adopted the cooking procedure previously described [23]. We noticed that flour is the pastry principal ingredient which is compound with starch $(70 \%)$, water $(16 \%)$, Gluten (11\%), Sugar (2\%) and fatty substance $(1 \%)$ [4]. We noticed also that the pastry height in the cake pan before cooking was all the time equal to $15[\mathrm{~mm}]$ and for each salts we read not only the pastry height after the cooking procedure but also its taste and texture to assess each salts swelling capacity. We showed in the following table (Table 9) the tests results and comparisons for all salts [23].

Table 9. Results of Swelling Capacity Salts Tests.

\begin{tabular}{|c|c|c|c|c|c|c|c|}
\hline & $\begin{array}{l}\text { Without } \\
\text { salt }\end{array}$ & $\begin{array}{l}\left(\mathrm{AH}_{2}^{-} / \mathrm{NH}_{4}^{+}\right) \\
100 \%\end{array}$ & $\begin{array}{l}\left(\mathrm{AH}^{2-} / 2 \mathrm{NH}_{4}{ }^{+}\right) \\
100 \%\end{array}$ & $\begin{array}{l}\mathrm{NaHCO}_{3} \\
100 \%\end{array}$ & $\begin{array}{l}\left(\mathrm{AH}_{2}^{-} / \mathrm{NH}_{4}^{+}\right) \\
75 \% \mathrm{NaHCO}_{3} \\
25 \%\end{array}$ & $\begin{array}{l}\left(\mathrm{AH}_{2}{ }^{-} / \mathrm{NH}_{4}{ }^{+}\right) 50 \% \\
\mathrm{NaHCO}_{3} 50 \%\end{array}$ & $\begin{array}{l}\left(\mathrm{AH}^{2-} / 2\right. \\
\left.\mathrm{NH}_{4}^{+}\right) 50 \% \\
\mathrm{NaHCO}_{3} 50 \% \\
\end{array}$ \\
\hline Mixture height [mm] & 15 & 15 & 15 & 15 & 15 & 15 & 15 \\
\hline Cake height [mm] & 18 & 22 & 23 & 35 & 29 & 32 & 33 \\
\hline $\begin{array}{l}\text { Height increase }(\mathrm{HI}) \text { in } \\
\text { comparison with } \\
\text { Without salt }[\mathrm{mm}]\end{array}$ & 0 & 4 & 5 & 17 & 11 & 14 & 15 \\
\hline $\begin{array}{l}\mathrm{NaHCO}_{3}(\mathrm{HI}) / \\
\text { Ammonium salts (HI) }\end{array}$ & - & 4.25 & 3.4 & 1 & 1.55 & 1.21 & 1.13 \\
\hline Taste & Neutral & Acid & Acid & Neutral & Lightly Acid & Very Lightly Acid & $\begin{array}{l}\text { Very Lightly } \\
\text { Acid }\end{array}$ \\
\hline Texture & $\begin{array}{l}\text { Very } \\
\text { compact }\end{array}$ & $\begin{array}{l}\text { Uniformly Very } \\
\text { Not much porous }\end{array}$ & $\begin{array}{l}\text { Uniformly Very } \\
\text { Not much porous }\end{array}$ & Porous & $\begin{array}{l}\text { Uniformly } \\
\text { Not much porous }\end{array}$ & $\begin{array}{l}\text { Uniformly } \\
\text { Not much porous }\end{array}$ & $\begin{array}{l}\text { Uniformly } \\
\text { Not much porous }\end{array}$ \\
\hline
\end{tabular}

According to the results in the table 9, the ammonium Di-hydrogenocitrate had 4.25 times less capacity to swell than the sodium carbonate but theoretically we was in a hurry for 7.5 times (cf. § 7.1). It was the same for the ammonium mono-hydrogenocitrate which had 3.4 times less capacity to swell than the sodium carbonate but theoretically we was in a hurry for 4.1 times (cf. § 7.1). These results was due to the water molecules and carbon dioxide $\mathrm{CO}_{2}$ formations from the ammonium Di-hydrogenocitrate and the ammonium mono-hydrogenocitrate. Water molecules formed are solvent and responsible of the ingredients repartition until the ammonium salts evaporation to form porous particularly uniform (Table 9). For these ammonium Di-hydrogenocitrate and the ammonium mono-hydrogenocitrate, water and carbon dioxide molecules were formed either by their dehydration and decarboxylation like a citric acid [13-24-26], either by the dehydration and decarboxylation of citric acid molecules formed (figure 7) and either by the esterification reaction [24] between the acid of the citric acid formed and the starch's alcohol functions [27-28] according to the figure
11. That explained the uniformly very not much porous of the ammonium Di-hydrogenocitrate and mono-hydrogenocitrate salts samples texture (table 9).

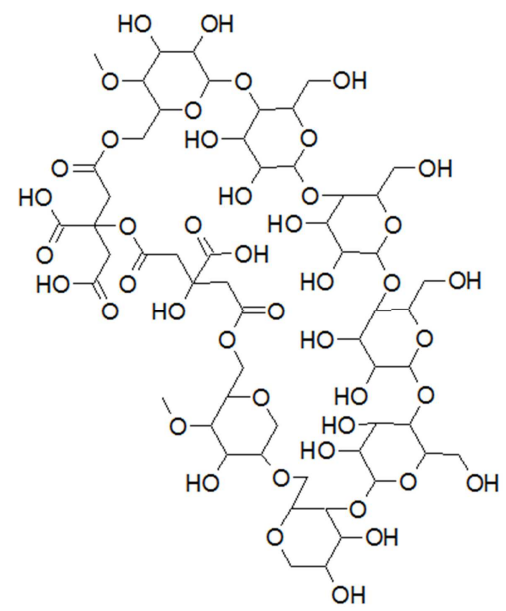

Figure 11. Esterification reactions Between Citric Acids and Starches Molecules. 


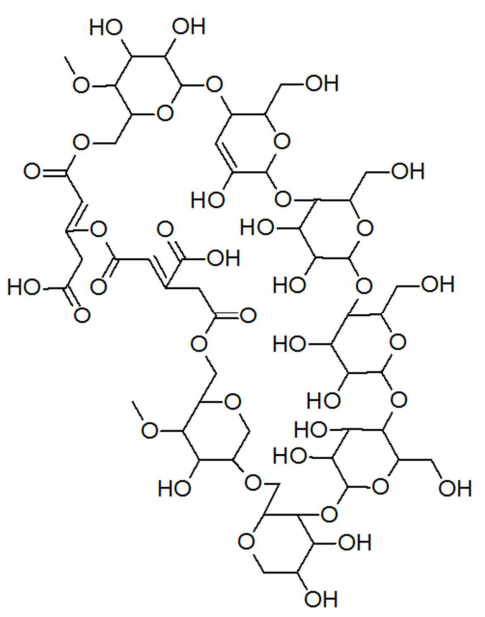

Figure 12. Dehydration and decarboxylation of alcohol and acid functions of the figure 11 molecule to obtain alkenes.

\section{Conclusion}

The crystallization of the ammonium Di-hydrogenocitrate and the ammonium mono-hydrogenocitrate obtained by the ammonia and the citric acid reaction using an ethanol as co-solvent while respecting the $\mathrm{pH}$ rule was not only easier but also energetically economical. The swelling test capacity of these salts by following a cooking procedure informed us the gases emissions like ammonia, carbon dioxide, water vapor and consequently the real formation of water molecules by esterification between citric acids and starches molecules. The molecules formed by this esterification reaction like the one showed by the figure 11 was interesting because in certain conditions like the cooking procedure that we adopted on the paragraph $\$ 7.2$, they are potential source of water molecules and carbon dioxide by dehydration and decarboxylation reactions (figure 12). Being given that the ammonium Di-hydrogenocitrate and the ammonium mono-hydrogenocitrate contains azote and citric acid which plays a significant role in biochemistry as metabolite of the Krebs' cycle, a major metabolic way at all the aerobic organism, it's possible in certain conditions to use these salts as fertilizer supplements.

\section{Acknowledgements}

We express our sincere thanks to E. S. P. A Polytechnics and Antananarivo University. Sincere gratitude also to GPCI department as well as Chemical Engineering Laboratory staff for its supports.

\section{References}

[1] OMRI, Citric acid and its salts, Technical Evaluation for the USDA National Organic Program February 17, 2015.

[2] Rawat A., BURGESS DJ. "Effect of ethanol as a processing co-solvent on the PLGA microsphere characteristics" Int. J. Pharm. 2010 Jul 15; 394(1-2): 99-105. Doj: 10.1016/j.ijpharm. 2010.05.013. Epub. 2010 May 22.
[3] M. Laffitte, F. Rouquerol La réaction chimique Tome 2. Aspects thermodynamiques (suite) et cinétiques, 1991, Eds. Masson p. 22.

[4] Wikipedia Encyclopedia on line.

[5] Silva AM, Kong X, Hider RC, Pharmaceutical Sciences Research Division, King's College London, London, UK «Determination of the pKa of the hydroxyl group in the alpha-hydroxycarboxylates citrate, malate and lactate by $13 \mathrm{C}$ NMR: implications for metal coordination in biological systems» http://www.ncbi.nlm.nih.gov/pubmed/19288211.

[6] Gougerot-Schwartz A. "Cosmétologie et dermatologie esthétique" Encyclopedie Méd. Chir. (2000) 7p.

[7] Andry Tahina Rabeharitsara, Marie Nicole Rabemananjara, Nambinina Richard Randriana' Haritiana Jeannelle Rakotonirina, Edouard Andrianarison' André Razafimandefitra, Baholy Robijaona Chemical Process Engineering Department (E. S. P. A), Antananarivo University, Antananarivo, Madagascar « Auto-Inflammation Test of Black Citric Acid Polymer (PN) and Fuel Oil (FO) Mixes - Coke Formation » American Journal of Applied Chemistry, Vol. 5, Issue Number 3, June 2017.

[8] M. Laffitte, F. Rouquerol La réaction chimique Tome 2. Aspects thermodynamiques (suite) et cinétiques, 1991, Eds. Masson p. 30 .

[9] O'Neil, M. J. (ed.). The Merck Index - An Encyclopedia of Chemicals, Drugs, and Biologicals. Cambridge, UK: Royal Society of Chemistry, 2013., p. 416.

[10] Budavari, S. (ed.). The Merck Index - An Encyclopedia of Chemicals, Drugs, and Biologicals. Whitehouse Station, NJ: Merck and Co., Inc., 1996., p. 87 https://pubchem.ncbi.nlm.nih.gov/compound/14923\#section

[11] M. Laffitte, f. Rouquerol La réaction chimique Tome 2. Aspects thermodynamiques (suite) et cinétiques, 1991, Eds. Masson annexe 24 .

[12] Raymond C Rowe, Paul J Sheskey, Marian E Quinn, Handbook of Pharmaceutical Excipients, Pharmaceutical Press and American Pharmacists Association, 2009, 6e éd., 888 p. (ISBN 978085369792 3), p. 40.

[13] Sammy Eric andriambolA Valorisation de l'acide citrique en polymères et en sels de mono- di- et tri-ammonium. Mémoire de fin d'étude en vue de l'obtention du diplôme d'Ingénieur en Génie Chimique. E. S. P. A. Université d'Antananarivo. 2013.

[14] A. G. Jones, Professor of Chemical Engineering, Department of Chemical Engineering, UCL (University College London), London, UK. Crystallization Process Systems.

[15] ethanol (anhydre) [archive], fiche de sécurité du Programme International sur la Sécurité des Substances Chimiques [archive].

[16] James E. Mark, Physical Properties of Polymer Handbook, Springer, 2007, 2e éd., 1076 p.(ISBN 0387690026, lire en ligne [archive]), p. 294.

[17] Haynes, William M., ed. (2011). CRC Handbook of Chemistry and Physics (92nd ed.). Boca Raton, FL: CRC Press. p. 3.246. ISBN 1439855110.

[18] E. Arunan, G. R. Desiraju, R. A. Klein, J. Sadlej, S. Scheiner, I. Alkorta, D. C. Clary, R. H., Crabtree, J. J. Dannenberg, P. Hobza, H. G. Kjaergaard, A. C. Legon, B. Mennucci, D. J. Nesbitt. Definition of the hydrogen bond (IUPAC Recommendations 2011) Pure Appl. Chem. 83, 1619 (2011). 
14 Andry Tahina Rabeharitsara et al: : Ammonium Di-Hydrogenocitrate and Mono-Hydrogenocitrate Synthesis by Citric Acid Neutralization with Ammonia Using Ethanol as Co-Solvent for the Crystallization - Swelling Test to Confirm Gases Emissions Capacity

[19] O'Neil, M. J. (ed.). The Merck Index - An Encyclopedia of Chemicals, Drugs, and Biologicals. 13th Edition, Whitehouse Station, NJ: Merck and Co., Inc., 2001., p. 89.

[20] Setrarivo andriambalohery, Etude de la formation d'acide sulfurique et d'ammoniac à partir du sulfate d'ammonium par du catalyseur acide l'acide citrique. Mémoire de fin d'études en vue de l'obtention du diplôme d'ingénieur en génie chimique 2011 - Ecole Supérieure Polytechnique d'Antananarivo (E.S.P.A) - Université d'Antananarivo.

[21] Atkins, P. W. (2006). Physical Chemistry. Oxford University Press. ISBN 0-19-870072-5. Section 7.4: The Response of Equilibria to Temperature.

[22] Franz HAAS, Handbook of wafer technologies - third revised and extended edition, October 2002.

[23] Maheriniaina Andriamasinoro andriamandroso, Valorisation du mono et di-hydrogenocitrate d'ammonium en levant. Mémoire en vue de l'obtention du diplôme de Licence Académique en génie des procédés chimiques et industriels - 2016 - Ecole Supérieure Polytechnique d'Antananarivo (E.S.P.A) Université d'Antananarivo.

[24] Andry Tahina Rabeharitsara, Marie Nicole Rabemananjara, Nambinina Richard Randriana, Edouard Andrianarison, André Razafimandefitra, Baholy Robijaona (ESPA), Chemical Process Engineering Department, Antananarivo University,
Antananarivo, Madagascar: Auto-Inflammation Test of Black Citric Acid Polymer (PN) and Fuel oil (FO) Mixes - Coke Formation. American Journal of Applied Chemistry in Vol. 5, Issue Number 3, June 2017.

[25] Marie Nicole Rabemananjara, Test d'auto-inflammation du mélange polymère noir ( $\mathrm{PN}$ ) et fuel-oil (FO), étude de formation de coke. Mémoire en vue de l'obtention du diplôme de Licence Académique en génie des procédés chimiques et industriels 2016 - Ecole Supérieure Polytechnique d'Antananarivo (E.S.P.A) - Université d'Antananarivo.

[26] Thomas Fenohery, Contribution à la valorisation de l'huile de palme en ester et polyester par estérification avec de l'acide citrique effet de l'acidité et du fer, Mémoire de fin d'étude en vue de l'obtention du diplôme d'Ingénieur en Génie Chimique. E.S.P.A. Université d'Antananarivo. 2013.

[27] Lalaina Sarah raholiarisoa, Auto-estérification de l'acide citrique en passant par une phase de chloration avec de l'acide chlorhydrique suivi d'une substitution électrophile, formation des monomères d'ester et éventuellement des polymères. Mémoire en vue de l'obtention du diplôme de Licence Académique en génie des procédés chimiques et industriels 2014 - Ecole Supérieure Polytechnique d'Antananarivo (E.S.P.A) - Université d'Antananarivo.

[28] Wikipedia Encyclopedia on line. L'amidon. 